reducing-sugars, but, needlessly, complicates the analysis, by rendering it imperative that the sucrose be separately estimated and subtracted from the extractive found, in order to arrive at a knowledge of the amount of extractive due to the coffee, upon which the ratio is based. The presence of milk or cream entirely vitiates the results, as milk-sugar is a reducing-sugar and as the presence of a small amount of milk or cream might escape detection, it is suggested that the centrifuging of about $10 \mathrm{cc}$. in a centrifuge such as is used for urinary sediments, or of a larger amount in a Babcock milk-testing machine, will quickly result in the identification and rejection of such samples that have had milk or cream added to them either accidentally or intentionally.

It has been found by us in laboratory practice applied to commercial samples, that about one-fourth of the adulterated samples contain a cereal in addition to the chicory. The detection of the cereal is easily made, easy by testing for starch (which is entirely absent in the beverage made from pure coffee) by taking $10 \mathrm{cc}$. of the liquid, acidulating with sulphuric acid and adding potassium permanganate solution, drop by drop, until the liquid is just decolorized, when a drop of iodine test-solution added to the filtrate gives the clear-blue starch reaction, which is ordinarily obscured by the dark color of the liquid.

The percentage of reducing-sugars in the extractive of a number of commercial products, is herewith given, as being of an informative character:

\begin{tabular}{|c|c|}
\hline 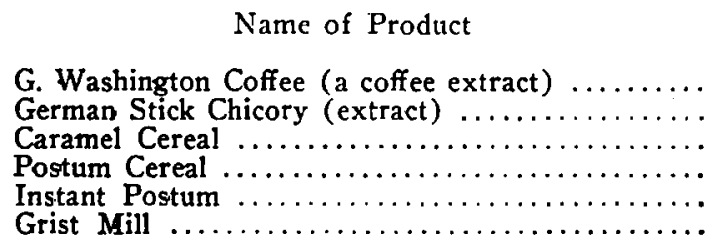 & $\begin{array}{l}\text { Percentage of Reducing-Sugars in } \\
\text { Extractive } \\
\text { less than } 1 \% \\
22.10 \\
13.69 \\
5.43 \\
6.36 \\
6.64\end{array}$ \\
\hline
\end{tabular}

The four last named are proprietary substitutes for coffee. All of them contained cereal, as shown by the starch-test above described.

\title{
COMPARISON OF THE PHYSICAL PROPERTIES OF SOME OFFICIAL VOLATILE OILS WITH SPECIAL REFERENCE TO THE REQUIREMENTS OF THE U. S. P., 1910.
}

FRANK RABAK.

Chemical Biologist, Drug-Plant and Poisonous-Plant Investigations. Bureau of Plant Industry.

The ninth decennial revision of the United States Pharmacopœia has resulted in numerous changes in the section devoted to volatile oils, especially with regard to the physical properties of the various oils. Among the properties described are color, odor, taste, specific gravity, optical rotation, and solubility, the refractive index being mentioned in only few instances. The importance of these properties should not be underestimated, as the varying quality of any volatile oil may be readily observed by means of them. Because of the inability of the 
senses, to measure accurately the color, odor, and taste of a volatile oil, these properties are necessarily somewhat less significant than those which admit of careful and accurate measurement. The color of a volatile oil, is a property which may, however, be influenced greatly, by a number of factors such as the condition of the plant, whether fresh, dry, or partly dry, the stage of growth, and the length of time of distillation. The last factor is especially important since, in numerous distillations of aromatic plants it has been observed that the first runnings are invariably lighter in color than the later portions of the oil. This is, probably, partly due to the fact that fractionation takes place during the distilling process, the lighter, most volatile and usually least colored portions of the oil, distilling over before the denser and higher-boiling constituents make their appearance. In order therefore to obtain a genuine sample of an oil it is of utmost importance that the distillation process be continued until extraction of the oil is complete. The odor and taste will be likewise affected, but the latter is less capable of being described than the former. Only pronounced differences, at best. can be observed by the sense of taste and smell, yet these properties are beneficial, and even necessary, in the preliminary examination of a volatile oil.

In direct contrast to the above properties, which are uncertain of expression, are specific gravity and optical rotation, both of which are readily determined and expressed in figures to admit of easy comparison. Specific gravity is, perhaps, the most important of the physical properties of volatile oils and is influenced very much by the source and condition of a plant, as well as by seasonal changes, the effects of these factors being reflected in the density of the oil. Optical rotation and likewise solubility, while possibly less important, are nevertheless dependent to a large extent upon the chemical composition of the oil, which, in turn, is modified by condition of distillation, ripeness of the plant and climatic conditions. Each physical property may be said to serve a more or less definite purpose in general examinations of volatile oils, before the application of special chemical methods for the determination of any definitely-known constiuents.

While a large number of aromatic plants have been under observation by the writer, only those which are officially recognized by the $U$. S. Pharmacopoia, will be considered here. The paper has been prepared with a two-fold object. First, a comparison of the physical properties of the oils with the requirements of the U. S. Pharmacopoia, 1910, will be made, and, secondly, the properties of each oil will be compared through several successive seasons, in order to show the effect of seasonal influence on the general characteristics of the oils.

The oils which will be discussed with respect to their physical properties, and compared with the limitations adopted by the U. S. Pharmacopoia, 1910, are as follows:-Chenopodium, Fennel, Lavender, Pennyroyal, Peppermint, Rosemary, Spearmint, and Thyme.

At the outset, it is essential to state that the above plants were grown in the same locality for several years. Each plant was distilled with steam, while in full bloom, the material being cut and distilled immediately, in order to prevent any changes which might be brought about by drying or partial-drying, and in order that the oils might be directly comparable from season to season. Distillation was continued in each case, until little or no oil was perceptible, when a 
small quantity of distillate was collected in a test tube, true samples of the oils being thereby obtained from the respective plants. The oils were subsequently filtered and kept in tightly-stoppered bottles, in a dark place, until the determinations were made.

The various physical properties as mentioned previously, were carefully determined for each oil, and the results tabulated.

Table I embodies the color, odor, and taste of the various oils distilled during the seasons 1907, 1908, 1909, and 1910. For the purpose of comparison, the requirements of the U. S. Pharmacopoia, 1910, are included in this table as well as the tables following.

Tabis I-Color. Omor and Taste.

\begin{tabular}{|c|c|c|c|c|c|}
\hline \multirow{2}{*}{ Oil } & \multirow{2}{*}{$\begin{array}{c}\text { Requirements } \\
\text { of U. S. P. } \\
1910 \text {, 9th Revision }\end{array}$} & \multicolumn{4}{|c|}{$\begin{array}{l}\text { Oils distilled during several successive seasons at Arlington } \\
\text { Experimental Farm }\end{array}$} \\
\hline & & 1907 & 1908 & 1909 & 1910 \\
\hline Chenopodium & $\begin{array}{l}\text { Colorless, or pale } \\
\text { yellow; character- } \\
\text { istic disagreeable } \\
\text { odor and taste. }\end{array}$ & $\begin{array}{l}\text { Light brown col- } \\
\text { or; penetrating } \\
\text { offensive o d o r ; } \\
\text { sharp and bitter } \\
\text { taste. }\end{array}$ & $\begin{array}{l}\text { Golden yellow col- } \\
\text { or; characteristic } \\
\text { offensive o d o r } \\
\text { very pungent and } \\
\text { bitter taste. }\end{array}$ & $\cdots \cdots \cdots \cdots$ & $\cdots \cdots \cdots \cdots$ \\
\hline Fennel. & $\begin{array}{l}\text { Colorless, or pale } \\
\text { yellow; character- } \\
\text { istic odor and } \\
\text { taste. }\end{array}$ & $\ldots \ldots \ldots \ldots$ & $\ldots \ldots \ldots \ldots$ & $\begin{array}{l}\text {-Very pale yellow } \\
\text { color; sweet pleas- } \\
\text { ant and aromatic } \\
\text { odor and taste. }\end{array}$ & $\begin{array}{l}\text { Pale yeliow col- } \\
\text { or; sweet fra- } \\
\text { grant odor; fatty, } \\
\text { sweet taste. }\end{array}$ \\
\hline Lavender & $\begin{array}{l}\text { Colorless, or yel- } \\
\text { low; characteris- } \\
\text { tic odor and taste. }\end{array}$ & $\ldots \ldots \ldots$ & $\begin{array}{l}\text { Pale yellow color; } \\
\text { pleasant fragrant } \\
\text { characteristic } \\
\text { odor; aromatic, } \\
\text { slightly bitter } \\
\text { taste. }\end{array}$ & $\begin{array}{l}\text { Golden yellow col- } \\
\text { or; agreeable } \\
\text { flowery character- } \\
\text { istic odor; aromat- } \\
\text { ic bitter taste. }\end{array}$ & $\begin{array}{l}\text { Pale brown color; } \\
\text { agreeable, flowery } \\
\text { odor; aromatic, } \\
\text { bitter taste. }\end{array}$ \\
\hline Pennyroyal & $\begin{array}{l}\text { Pale yellow color; } \\
\text { characteristic } \\
\text { odor and taste. }\end{array}$ & $\ldots \ldots \ldots \ldots$ & $\begin{array}{l}\text { Bright yellow col- } \\
\text { or; minty charac- } \\
\text { teristic odor; min- } \\
\text { ty, slightly bitter } \\
\text { taste. }\end{array}$ & $\begin{array}{l}\text { Very paje yellow; } \\
\text { pleasant, minty } \\
\text { odor, p u n g e t } \\
\text { minty taste. }\end{array}$ & $\begin{array}{l}\text { Yellowish color; } \\
\text { o d or agreeable; } \\
\text { not noticeably } \\
\text { minty; bitter pun- } \\
\text { gent, minty taste. }\end{array}$ \\
\hline Peppermint . & $\begin{array}{l}\text { Colorless; strong } \\
\text { odor of pepper- } \\
\text { mint; p u g e } \mathrm{t} \text { - } \\
\text { cooling taste. }\end{array}$ & $\begin{array}{l}\text { Greenish-yellow } \\
\text { color; agreeable } \\
\text { minty odor; pun- } \\
\text { gent cooling taste. }\end{array}$ & $\begin{array}{l}\text { L i g h t yellowish } \\
\text { green; pleasant } \\
\text { minty odor; very } \\
\text { pungent; cooling } \\
\text { taste. }\end{array}$ & $\begin{array}{l}\text { Pale y e } 110 \mathrm{w} \\
\text { agreeable, minty } \\
\text { od or r pungent } \\
\text { minty taste. }\end{array}$ & $\begin{array}{l}\text { Pale yellow; mild, } \\
\text { agreeable, minty } \\
\text { odor; fatty pun- } \\
\text { gent, c o o l i n s } \\
\text { taste. }\end{array}$ \\
\hline Rosemary & $\begin{array}{l}\text { Colorless, or pale } \\
\text { yellow; character- } \\
\text { istic odor; cam- } \\
\text { phoraceous taste. }\end{array}$ & $\ldots \ldots \ldots \ldots$ & $\ldots \ldots \ldots \ldots$ & $\begin{array}{l}\text { Yellow c o I o r ; } \\
\text { pleasant, aromatic } \\
\text { odor; slightly bit- } \\
\text { ter, camphorace- } \\
\text { ous taste. }\end{array}$ & $\cdots \ldots \ldots \ldots$ \\
\hline Spearmint & $\begin{array}{l}\text { Colorless, yellow } \\
\text { or greenish yel- } \\
\text { low; characteris- } \\
\text { tic odor and taste. }\end{array}$ & $\begin{array}{l}\mathrm{L} \text { i g h t yellowish } \\
\text { color; sharp, aro- } \\
\text { matic, characteris- } \\
\text { tic taste. }\end{array}$ & $\begin{array}{l}\text { Light green color; } \\
\text { agreegble, charac- } \\
\text { teristic odor ; char- } \\
\text { acteristic, minty, } \\
\text { pungent taste. }\end{array}$ & $\begin{array}{l}\text { Pale green; agree- } \\
\text { able, fowery odor; } \\
\text { bitter, pungent, } \\
\text { aromatic taste. }\end{array}$ & $\begin{array}{l}\text { Dark golden yel- } \\
\text { low; strong aro- } \\
\text { matic, charcteris. } \\
\text { tic odor; very } \\
\text { pungent, bitter, } \\
\text { characteristic } \\
\text { taste. }\end{array}$ \\
\hline $\begin{array}{c}\text { Thyme } \\
:\end{array}$ & $\begin{array}{l}\text { Colorless, or red; } \\
\text { characteristic odor } \\
\text { and taste. }\end{array}$ & $\begin{array}{l}\text { Light brown col- } \\
\text { or; strong thymol- } \\
\text { like odor; ex- } \\
\text { tremely pungent } \\
\text { taste. }\end{array}$ & $\begin{array}{l}\text { G o l d e n yellow, } \\
\text { mild, not unpleas- } \\
\text { an t aromatic } \\
\text { odor; very pun- } \\
\text { gent taste. }\end{array}$ & $\begin{array}{l}\text { Light brown col- } \\
\text { or ; f o w e ry } \\
\text { strong, thyme-like } \\
\text { odor; very pun- } \\
\text { gent taste. }\end{array}$ & $\begin{array}{l}\text { Brownish red col- } \\
\text { or; thymol-like, } \\
\text { n o t unpleasant } \\
\text { o d o r ; intensely } \\
\text { pungent taste. }\end{array}$ \\
\hline
\end{tabular}

- Oils from fruiting tops.

From Table I it will be seen that the Chenopodium oils distilled in 1907 and 1908, were darker in color than the requirements of the Pharmacopcia. Fennel oils distilled in 1909 and 1910 , corresponded more closely to the color requirements: Lavender oils, on the other hand; from three successive season's crops, 
showed some variation in color, from pale-yellow to a pale-brown, probably because of differences in the plant material due to seasonal conditions. Pennyroyal and rosemary oils corresponded fairly closely in color to the Pharmacopoeial requirements, while peppermint and spearmint varied greatly from year to year. Thyme oils from seasons of 1907, 1908, 1909, and 1910 ranged from a golden-yellow to brownish-red color, a colorless oil never having been distilled during the number of seasons in which this plant has been under observation. The odor and taste of the various oils, are described in most cases as "characteristic," hence a comparison of these properties could not be made, other than among the individual oils from season to season. The properties of odor and taste, will be seen to differ considerably in some cases, doubtless due to a variation in composition of the respective oils.

It would seem, from the data presented, that the color of an oil, is a property which is subject to wide variation, the odor and taste also showing differences sufficient to be more or less easily detected by the senses. While descriptions of these properties depend largely upon individual sensitiveness, a careful analytical description of odor and taste would be decidedly advantageous.

Table II--Specific Gravity.

\begin{tabular}{|c|c|c|c|c|c|}
\hline \multirow{2}{*}{ Oils } & \multirow{2}{*}{ 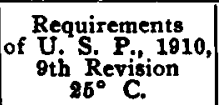 } & \multicolumn{4}{|c|}{$\begin{array}{l}\text { Oil distilled during several successive seasons at Arlington } \\
\text { Experimental Farm }\end{array}$} \\
\hline & & 1907 & 1908 & 1909 & 1910 \\
\hline $\begin{array}{l}\text { Chenopodium } \\
\text { Fennel ...... } \\
\text { Lavender } \ldots \\
\text { Pennyroyal } \ldots \\
\text { Peppermint } \ldots \\
\text { Rosemary . . . } \\
\text { Spearmint } \ldots \\
\text { Thyme ..... }\end{array}$ & $\begin{array}{l}0.956 \text { to } 0.980 \\
0.958 \text { to } 0.978 \\
0.875 \text { to } 0.888 \\
0.980 \text { to } 0.935 \\
0.894 \text { to } 0.914 \\
0.894 \text { to } 0.912 \\
0.914 \text { to } 0.984 \\
0.894 \text { to } 0.989\end{array}$ & 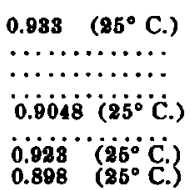 & 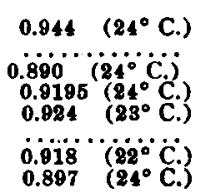 & 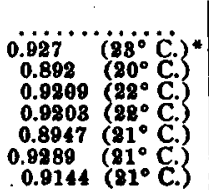 & 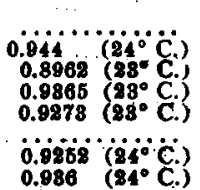 \\
\hline
\end{tabular}

- Uils from fruiting tops.

It will be observed, from Table II, that the specific gravities of the Chenopodium oils, easily fall within the requirements prescribed by the Pharmacopoeia. The densities of the fennel oils, are below the standard, which is, doubtless, due to the fact that these oils were distilled in 1909 and 1910, from the partly ripe fruiting-tops and from ripe fruiting-tops respectively, while the Pharmacopoeia specifies the oil from ripe fruit. Lavender oils from the seasons of .1908, 1909, and 1910 are uniformly regular and higher in specific gravity than the requirements. These oils were distilled from fully matured fresh flowering-tops of lavender. Since this oil is produced in foreign countries exclusively, it is probable that the higher densities of the American oils are due to climatic and soil conditions contingent upon geographical sources. No important differences were revealed in the specific gravities of the pennyroyal oils included in the table, the slightly higher specific gravity of the 1910 oil, being due to the slightly lower temperature at which it was observed. The peppermint oils from the four successive seasons are perhaps somewhat higher than the upper limit specified by the Pharmacopoia. This is especially true of the oils distilled during the seasonis of 1908, 1909, and 1910. The slightly lower temperature at which the densities were taken, would probably not account for the higher figures obtained. Rosemary 
and spearmint oils shows no noteworthy discrepancies, while only the thyme oil of 1910 is beyond the upper limit of the Pharmacopœial requirement.

It is most evident that the specific gravity, is a property which is materially influenced by the numerous factors and conditions attending the distillation process, and the nature and condition of the plant material as influenced by seasonal variations.

Table III-Optical Rotation.

\begin{tabular}{|c|c|c|c|c|c|}
\hline \multirow{2}{*}{ Oils } & \multirow{2}{*}{$\begin{array}{c}\text { Requirements } \\
\text { of U. S. P., 1010, } \\
\text { gth Revision } \\
100 \mathrm{~mm} \text {. tubes }\end{array}$} & \multicolumn{4}{|c|}{$\begin{array}{l}\text { Oil distilled during several successive seasons at Arlington } \\
\text { Experimental Farm }\end{array}$} \\
\hline & & 1907 & 1008 & 1909 & 1010 \\
\hline $\begin{array}{l}\text { Chenopodium } \\
\text { Fennel } \\
\text { Lavender ... } \\
\text { Pennyroyal . } \\
\text { Peppermint . } \\
\text { Rosemary ... } \\
\text { Spearmint ... } \\
\text { Thyme ..... }\end{array}$ & $\begin{array}{l}-4^{\circ} \text { to }-10^{\circ} \\
+12^{\circ} \text { to } 24^{\circ} \\
-1^{\circ} \text { to }-10^{\circ} \\
+17^{\circ} \text { to } 28^{\circ} \\
-20^{\circ} \text { to } 35^{\circ} \\
\ldots \ldots \ldots \ldots \ldots \\
-35^{\circ} \text { to } 50^{\circ} \\
\text { Slightly } \\
\text { lavogyrate }\end{array}$ & 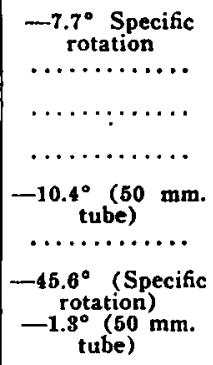 & $\begin{array}{c}-6.6^{\circ} \text { Specific } \\
\text { rotation } \\
\ldots \ldots \ldots \ldots \ldots \\
-4^{\circ}(50 \mathrm{~mm} . \\
\text { tube) } \\
+34.4^{\circ}(50 \mathrm{~mm} . \\
\text { tube) } \\
-4.5^{\circ} \text { (50 mm. } \\
\text { tube) } \\
\ldots \ldots \ldots \ldots \ldots \\
-27.8^{\circ}(50 \mathrm{~mm} . \\
\text { tube) } \\
-0.6^{\circ}(50 \mathrm{~mm} . \\
\text { tube) }\end{array}$ & $\begin{array}{c}\cdots \cdots \cdots \cdots \cdots \\
+14.9^{\circ}(50 \mathrm{~mm} . \\
\text { tube) } \\
-6.5^{\circ} \quad(50 \mathrm{~mm} . \\
\text { tube) } \\
+28.6^{\circ}(50 \mathrm{~mm} . \\
\text { tube) } \\
-10.6^{\circ}(50 \mathrm{~mm} . \\
\text { tube) } \\
-2.4^{\circ} \text { (50 } \mathrm{mm} . \\
\text { tube) } \\
-16.1^{\circ} \text { (50 mm. } \\
\text { tube) } \\
-1.1^{\circ} \text { (50 mm. } \\
\text { tube) }\end{array}$ & 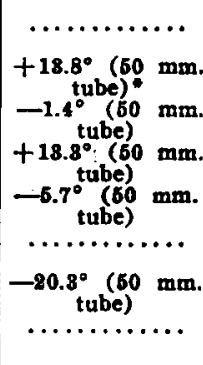 \\
\hline
\end{tabular}

- Oils from fruiting tops.

The optical rotation of the Chenopodium oils, as shown, fall well within the limits prescribed by the Pharmacopoia. The fennel oils, as in the case of the specific gravities, are higher in rotatory power than the limits of the Pharmacopceia this being due in all probability to the state of ripeness of the material when distilled, as previously discussed. The rotation of the lavender oils, shows much variation from year to year, the oil from the 1909 crop being considerably higher than the limit of optical rotation of the Pharmacopœia. The pennyroyal oils likewise, differ in rotation from season to season, the oils of the 1908 and 1909 crop being conspicuously, higher than the standards, especially if reduced to terms of rotation in a $100 \mathrm{~mm}$. tube, only the oil of the 1910 crop falling within the limits of rotation. Matked! differences in rotation, are also noted in peppermint and spearmint oils during four successive seasons, varying from $-4.5^{\circ}$ to $-10.6^{\circ}$ in the former and $-16.1^{\circ}$ to $-27.3^{\circ}$ in the latter, all observations being taken in a $50 \mathrm{~mm}$. tube. Peppermint oils, from the 1908 and $1910 \mathrm{crops}$, are below the minimum optical rotation adopted by the Pharmacopoia. The oil of the 1908 crops of spearmint, shows an optical rotation above that of the maximum of the Pharmacopoia. The thyme oils were slightly lævogyrate, varying from $-0.6^{\circ}$ to $-1.3^{\circ}$ in a $50 \mathrm{~mm}$. tube.

In the matter of the optical rotation it is again obvious that variability in this property is more or less marked, showing that the composition of the oils change somewhat from season to season depending upon the numerous factors previously mentioned. 
TABLE IV-SOLubILITY.

\begin{tabular}{|c|c|c|c|c|c|}
\hline \multirow{2}{*}{ Oils } & \multirow{2}{*}{$\mid \begin{array}{c}\text { Requirements } \\
\text { of } \mathbf{U}_{\text {th }} \text { S. P., 1910, } \\
\text { Revision }\end{array}$} & \multicolumn{4}{|c|}{$\begin{array}{l}\text { Oils distilled during several successive seasons at Arlington } \\
\text { Experimental Farm. }\end{array}$} \\
\hline & & 1807 & 1908 & 1908 & 1910 \\
\hline Chenopodium & $\begin{array}{l}8 \text { vols. } \\
70 \% \text { alcohol }\end{array}$ & $\mid 80 \%$ alcohol clear $\begin{array}{c}1 \text { vol. } \\
\text { solution }\end{array}$ & $\begin{array}{l}0.75 \text { vol. } 80 \% \text { al- } \\
\text { cohol clear solu- } \\
\text { tion. }\end{array}$ & $\ldots \ldots \ldots \ldots$ & $\ldots \ldots \ldots \ldots$ \\
\hline Fennel & $\begin{array}{l}8 \text { vols. } \\
80 \% \text { alcohol } \\
1 \text { vol. } \\
90 \% \text { alcohol }\end{array}$ & $\ldots \ldots \ldots \ldots$ & $\ldots \ldots \ldots \ldots$ & $\begin{array}{l}\text { Turbid in } 12 \\
\text { vols. } 80 \% \text { alcohol. } \\
2 \text { yols. } 80 \% \text { alco- } \\
\text { hol with clear so- } \\
\text { lution. }\end{array}$ & $\begin{array}{l}8.6 \text { vols. } 80 \% \bar{c} \\
\text { alcohol. Clear in } \\
\text { excess. }\end{array}$ \\
\hline Lavender .. & $\begin{array}{l}8 \text { vols. } \\
70 \% \text { alcohol }\end{array}$ & $\ldots \ldots \ldots \ldots$ & $\begin{array}{l}0.75 \text { vol. } 80 \% \text { al- } \\
\text { cohol clear solu- } \\
\text { tion. }\end{array}$ & $\begin{array}{l}1.2 \text { vols. } 80 \% \text { al- } \\
\text { cohol, }\end{array}$ & $\begin{array}{l}0.8 \text { vol. } 80 \% \text { al- } \\
\text { cohol. Turbid in } \\
4 \text { vols. or more. }\end{array}$ \\
\hline Pennyroyal & $\begin{array}{c}8 \text { vols. } \\
\text { ro\% alcohol }\end{array}$ & $\ldots \ldots \ldots \ldots$ & $\begin{array}{l}1 \text { vol. } 80 \% \text { alco- } \\
\text { hol slightly tur- } \\
\text { bid on further di- } \\
\text { lution. }\end{array}$ & $\mid \begin{array}{lcc}0.5 \text { rol. } 80 \% & \text { al- } \\
\text { cohol. } & \text { Clear } & \text { so- } \\
\text { lution. } & 1 & \end{array}$ & $\begin{array}{l}\text { All proportions in } \\
80 \% \text { alcohnl. }\end{array}$ \\
\hline Peppermint & $\begin{array}{l}\text { a vols. } \\
\text { ro\% alcohol with } \\
\text { only slight opales- } \\
\text { cence. }\end{array}$ & $\begin{array}{l}1.5 \text { vols. } 80 \% \\
\text { clear solution }\end{array}$ & $\begin{array}{l}1.85 \text { vols. } 80 \% \text { a)- } \\
\text { cohol clear solu- } \\
\text { tion. }\end{array}$ & $\begin{array}{l}1.8 \text { vols. } 80 \% \text { al- } \\
\text { cohol; turbid with } \\
8 \text { vols. or more. }\end{array}$ & $\begin{array}{l}0.6 \text { vol. } 80 \% \text { at. } \\
\text { cohol; turbid with } \\
8 \text { vols. or more. }\end{array}$ \\
\hline Rosemary .. & $\begin{array}{l}10 \text { vols. } 80 \% \text { al. } \\
\text { cohol. }\end{array}$ & $\ldots \ldots \ldots \ldots$ & $\ldots \ldots \ldots \ldots$ & $\begin{array}{l}\text { Insoluble in } 80 \% \\
\text { alcohol with clear } \\
\text { solution. } 0.75 \\
\text { vol. } 90 \% \text { alcotiol. }\end{array}$ & $\ldots \ldots \ldots \ldots$ \\
\hline Spearmint & $\begin{array}{l}1 \text { vol. } 80 \% \text { alco- } \\
\text { hol; cloudy on } \\
\text { further dilution. }\end{array}$ & $\begin{array}{l}1 \text { vol. } 80 \% \text { alco- } \\
\text { hol clear solution. }\end{array}$ & $\begin{array}{l}\text { Turbid in all pro- } \\
\text { portions with } 80 \% \\
\text { alcohol. } 1 \text { vol. } \\
90 \% \text { alcohol } \\
\text { cloudy on further } \\
\text { dilution. }\end{array}$ & $\begin{array}{l}1 \text { vol. } 80 \% \text { alco- } \\
\text { hol; turbid with } \\
2 \text { vols. or more. }\end{array}$ & $\begin{array}{l}0.4 \text { 7ol. } 80 \% \text { al. } \\
\text { cohol; turbid with } \\
8 \text { vols. or more. }\end{array}$ \\
\hline Thyme .. & $\begin{array}{l}\text {. vols. } 80 \% \text { alco- } \\
\text { hol. }\end{array}$ & $\begin{array}{l}1 \text { vol. } 80 \% \text { alco- } \\
\text { hol clear solution }\end{array}$ & $\begin{array}{l}\text { 9 vols, } 80 \% \text { alco- } \\
\text { hol with turbidity. } \\
1 \text { vol. } 00 \% \text { alco- } \\
\text { hol, faint turbid- } \\
\text { ity when further } \\
\text { diluted. }\end{array}$ & $\begin{array}{l}1.6 \text { rols. } 80 \% \text { al- } \\
\text { cohol; clear on } \\
\text { further dilution. }\end{array}$ & $\begin{array}{l}1 \text { vol. } 80 \% \text { clear } \\
\text { on furtber dilu. } \\
\text { tion. }\end{array}$ \\
\hline
\end{tabular}

- Oils frow fruiting topa.

It is unfortunate that the solubilities of all the oils in question, were determined with $80 \%$ and $90 \%$ alcohol, the Pharmacopoial requirements specifying $70 \%$ alcohol in several cases. However, the results will at least admit of comparisons being made of the solubility of the oils from one season to another.

The solubility of the Chenopodium oils from crops of 1907 and 1908, vary but slightly.

The fennel oils are widely separated with respect to solubility in $80 \%$ alcohol; the oil of the 1909 crop being turbid in 12 volumes of $80 \%$ alcohol, while the oil of the 1910 crop dissolved in $21 / 2$ volumes of $80 \%$ alcohol with a clear solution The latter oil being distilled from ripe fruiting-tops, probably accounts for its much greater solubility. No doubt distinct differences exist between the composition of these two oils,-the oil from the partly unripe fruiting-tops consisting undoubtedly of a larger proportion of terpenic compounds.

Distinct differences in the solubility of the lavender oils, are also disclosed, as may be seen from the table. Comparison with the requirements of the Pharmacopoia, are incapable of being made, in case of lavender and pennyroyal oils, because of the employment of alcohol of different percentage strength. In a like 
manner, pennyroyal oils from 1908, 1909, and 1910 crops, show considerable diversity with regard to their solubility in $80 \%$ alcohol. Peppermint oils from the four seasons crops exhibited very constant solubilities in $80 \%$ alcohol, the 1910 oil being most soluble. Rosemary oil ditsilled from 1909 crop, was found to be insoluble in $80 \%$ alcohol to make a clear solution; the Pharmacopoial requirement of the oil being 10 volumes of $80 \%$ alcohol. Spearmint oils exhibited decidedly variable solubility in $80 \%$ alcohol. The oil from the 1908 crop, was insoluble to a clear solution in $80 \%$ alcohol while the 1910 oil, in direct contrast, was soluble in 0.4 volume, becoming turbid in excess of two volumes of $80 \%$ alcohol.

The thyme oils distilled during the four successive seasons, were soluble in one to two volumes of $80 \%$ alcohol, all being within the requirements of the Pharmacopœia in this respect.

The results of the comparison of physical properties of the several official volatile oils, are such as to clearly indicate that conditions of cultivation, harvest, and distillation affect the physical constants of the oils. It is noteworthy of mention, in connection wtih the data presented, that all of the plants from which the above oils were obtained, were grown and distilled in the same locality, under identical conditions of harvest and distillation, yet variations are evident in the properties of the volatile oils. That seasonal conditions affect the composition of the oils, can hardly be doubted, from the comparisons of the several physical properties in the foregoing pages. The variations in specific gravity, optical rotation and solubility, are especially significant, since these properties bear direct relationship to the chemical composition of the oils. In some instances only were the constants of the oils within the limits of the Pharmacopøial requirements, yet the oils under observation were distilled with utmost care from material carefully grown and harvested, and therefore, must be considered as true, authentic samples.

\section{Discussion.}

Mr. AsHer: I would like to ask Dr. Stockberger whether other analyses have been made of these oils at various times, that is for instance, the oils made in 1907; whether analyses were made in 1910, and so on. My object in asking that question is this. I have done a great deal of work with the pinenes. We have examined, in the experiments we have conducted, these oils for solubility, refractive index and after severa! years found these possessed differen constants from those found when previously tested and no doubt the oils taken as standards by the pharmacopoia were not taken from fresh samples, as in this case and very much of the difference of the constants is no doubt due to some changes due to time.

DR Stockberger: Yes, samples of these oils have been examined from time to time and in many cases they have been found to vary with time in respect to their constants. On the other hand the figures shown in these tables were obtained from freshly distilled oils, and are presented to show the variations in these oils according to the season in which they were produced.

Mr. Asher: Just one further question in that regard, Mr. Stockberger. Did the gentleman who did the work later test these samples and did they then correspond wtih the samples in the pharmacopoia?

Dr. STOck berger: I am unable to answer that absolutely, because it is a special point with reference to the author's work which I am not sufficiently well acquainted with, to enable me to make a categorical answer. The intent of the author of this paper is to show that absolutely authentic material was worked with and that it is quite possible to have an authentic oil which does not conform to pharmacopoial requirements.

Mr. Charles T. P. Fennel, of Cincinnati: Were the oils ever tested for moisture?

Dr. Stockberger: Yes, sir. The oils were dry.

MR. FEN NEL: You are sure of that? I made a series of experiments a good many years ago, and I claim that quite a number of these oils contained water. I recall very distinctly the oil of cloves contained two percent. water. My claim for content of water was denied 
by manufacturers of volatile oil, especially one, but years afterwards the sample in question was picked out of the list presented and the distiller admitted it contained two percent. ot water. The records of the Association gave the data but I am not able to recall the time it was published.

Mr. Stockberger: I know it has been Mr. Rabak's custom in working with these oils to take all precautions, so far as possible, to remove moisture from the oil. Whether it was absolutely removed or not, of course, it is impossible for me to say, but I know that is my impression, that they were moisture free samples.

\section{NOTES ON A NEW ALKALOID FOUND IN NUX VOMICA.*}

\section{HUGO H. SCHAEFER.}

We find from time to time in pharmaceutical literature, reports of the discovery of new alkaloids in nux vomica beans, that is, alkaloids other than strychnine or brucine. In the Jour. Chem. Soc. (39-457), Shenstone reports the finding of an alkaloid freely soluble in warm water. After describing the substance, the author states that it is probably brucine with some persistent impurity. In the Pharm. Jour. (III, XIV, 1025) Dunston reports the discovery of a glucoside in nux vomica, which he terms loganin. Desnoir (Jahresbericht 50-54, p. 48) describes a new nux vomica alkaloid, which he calls igasurine. This, he claims, is an intensely bitter substance, giving tests entirely different from those of strychnine or brucine. Again, in Gmelin (XVII-589), we find that igasurine is a very bitter substance resembling brucine, but more soluble in water. Schutzenberg (Am. Jour. Pharm., 1858-535) reports that igasurine is really composed of nine different and distinct alkaloids. He separates these by fractional crystallizations and gives a brief description of each one. Finally we find, in Am. Jour. Pharm. (1872-256, Jörgenston), evidence that there is no such alkaloid as igasurine, or at least, that the substance so-called, can be readily converted into brucine, by treating with potassium iodide, filtering off and regenerating the alkaloid, which will be found to be brucine.

We therefore see, from the above contradicting statements, that it is an open question as to whether such an alkaloid as igasurine really exists. However, the author now wishes to report the finding of an alkaloid in nux vomica, which is totally different from strychnine, brucine, or any of the igasurines, as described in literature, and which alkaloid he proposes to call struxine.

This alkaloid makes its appearance during the process of manufacturing strychnine. In neutralizing the acid-solution of the raw alkaloidal sulphates of nux vomica, the new alkaloid separates out as a base, when the liquors become just neutral, or are still slightly acid, while strychnine and brucine remain in solution as sulphates. It was found that only few lots of nux vomica beans contained this substance, and the quantities, in those which did contain it, differed greatly with different lots. Careful record was made of the beans which yielded this new alkaloid, and this proved that all such beans were from shipments made from Cochin-China. "Those lots which consisted mostly of small beans, insect-eaten

\footnotetext{
* Read before Scientific Section at Detroit.
} 